Jurnal Akuntansi dan Investasi, Vol. 19 No. 1, Hlm: 76-91 Januari 2018

Artikel ini tersedia di website: http://journal.umy.ac.id/index.php/ai

DOI: $10.18196 /$ jai.190193

\title{
Studi Kasus Fenomena Tingkat Serapan Anggaran pada Satuan Kerja Perangkat Daerah
}

\author{
Perdana Kusuma Negara ${ }^{1}$; Lilik Handajani ${ }^{2}$; Lukman Effendy ${ }^{2}$ \\ ${ }^{1}$ Biro Umum Setda Provinsi Nusa Tenggara Barat, Indonesia \\ ${ }^{2}$ Magister Akuntansi, Universitas Mataram, Nusa Tenggara Barat, Indonesia
}

\begin{tabular}{l}
\hline A R T I C L E I N F O \\
\hline Article history: \\
received 23 Mar 2017 \\
reviewed 12 Apr 2017 \\
revised 04 Nov 2017 \\
accepted 11 Nov 2017
\end{tabular}

Keywords:

Absorption Budgets;

APBD; Biro Umum;

Phenomenom

\begin{abstract}
A B S T R A C T
This Study aims to identify factors causing the low absorption budget local government units (SKPD) especially in early year at Biro Umum Setda Provinsi Nusa Tenggara Barat. To get deeply understanding and to find objective of research, this study uses qualitative method namely case study approach. In this study the authors emphasize on the point of view of individuals/actors who have experience in terms of financial management and disbursement of funds, not from the views of the organization. The results of this study provide an illustration that there are three factors affecting the absorption rate of the budget on Biro Umum Setda Provinsi NTB after being identified using data analysis techniques from Miles and Huberman. Those dominant factors are policy, administratition and human resource. These three factors have a strong impact on the budget absorption rate which tends to be low in early year and as a result occur accumulation of budget in the end of the year.
\end{abstract}

(C) 2018 JAI. All rights reserved

\section{PENDAHULUAN}

Anggaran memiliki fungsi sebagai alat perencanaan dan sebagai alat pengendalian. Anggaran sebagai alat perencanaan mengindikasikan target yang harus dicapai oleh pemerintah, sedangkan anggaran sebagai alat pengendalian mengindikasikan alokasi sumber dana publik yang disetujui legislatif untuk dibelanjakan (Putri dan Fachruzzaman, 2014). Setelah memasuki era reformasi, pemerintah mengesahkan UndangUndang Nomor 22 tahun 1999 tentang Pemerintah Daerah atau sering juga disebut sebagai Undang-Undang Otonomi Daerah. Diberlakukannya Undang-Undang tersebut menjadi awal sejarah dimulainya era otonomi daerah dimana siklus keuangan daerah yang awalnya berpusat di pemerintah pusat kini diserahkan kepada daerah untuk mengelola keuangannya sendiri dalam bentuk Anggaran Pendapatan Dan Belanja Daerah (APBD). Penyusunan rancangan APBD berpe-doman pada Rencana Kerja Pemerintah Daerah (RKPD) dalam rangka mewujudkan tercapainya tujuan bernegara (Mahsun dan Heribertus, 2011).
Instrumen kebijakan fiskal pemerintah dalam menggerakkan perekonomian salah satunya adalah melalui konsumsi pemerintah (belanja/pengeluaran pemerintah). Pada dasarnya pengeluaran pemerintah tersebut bertujuan untuk menyediakan barang dan jasa, serta memenuhi kebutuhan dasar masyarakat yang tidak dapat disediakan oleh pihak swasta. Namun seiring dengan bergulirnya era otonomi daerah hingga sekarang, terjadi sebuah fenomena yang menarik yaitu minimnya penyerapan APBD di sebagian besar wilayah Indonesia.

Kegagalan mengoptimalkan penyerapan anggaran ini mengakibatkan hilangnya manfaat belanja, karena dana yang dialokasikan ternyata tidak semuanya dapat dimanfaatkan. Apabila pengalokasian anggaran efisien, maka keterbatasan sumber dana yang dimiliki dapat dioptimalkan untuk mendanai kegiatan strategis. Sumber-sumber penerimaan yang terbatas mengharuskan pemerintah menyusun prioritas kegiatan dan pengalokasian anggaran yang efektif dan efisien. Data yang dipublikasikan oleh Kementerian Keuangan pada tahun anggaran 2013 untuk semester pertama penyerpan anggaran belanja pemerintah rata-rata hanya mencapai $35,2 \%$, untuk tahun anggaran 
2014 angka pencapaian sebesar 37,5\%. Sedangkan untuk tahun anggaran 2015 hanya mencapai $33,1 \%$.

Fenomena tersebut terjadi juga di Provinsi Nusa Tenggara Barat (NTB), terutama pada awal tahun anggaran atau semester pertama (triwulan I dan II). Namun demikian berbeda pada saat menjelang akhir tahun anggaran, instansi pemerintah berusaha menyerap anggaran mendekati $100 \%$, agar tidak ditetapkan penyerapan anggarannya rendah. Sesuai data serapan APBD Provinsi NTB dari Biro Administrasi Pembanguan Setda Provinsi NTB, pada tiga tahun terakhir yaitu anggaran 2013 semester pertama serapan anggaran sebesar 35,39 \% dan pada akhir tahun serapan anggaran sebesar 92,70\%, sehingga terjadi deviasi sebesar 57,31 \% yang diserap menjelang akhir tahun anggaran. Begitu juga tahun anggaran 2014, pada semester pertama serapan anggaran sebesar 41,39\% dan pada akhir tahun sebesar 92,51\% sehingga deviasi sebesar 51,12\%. Sedangkan tahun anggaran 2015, serapan anggaran semester pertama sebesar 32,95\% dan pada akhir tahun sebesar $89,44 \%$ sehingga deviasi sebesar $56,49 \%$.

Berdasarkan fenomena yang terjadi tentunya ini menimbulkan permasalahan karena tidak proporsionalnya penyerapan anggaran disepanjang tahun anggaran. Hal ini disebabkan pola penyerapan anggaran menunjukan kecenderungan yang relatif sama setiap tahunnya, yaitu mulai meningkat pada pertengahan triwulan ketiga dan puncaknya pada triwulan keempat, sementara pada triwulan-triwulan sebelumnya -awal tahun- meningkat secara landai dan hampir stagnan. Selain itu, proses pengajuan dokumen pertanggungjawaban yang menumpuk diakhir tahun dapat menimbulkan masalah lain seperti kurangnya pengawasan terhadap kelengkapan dokumen pertanggungjawaban. Karena mengejar target realisasi dan juga terbentur dengan waktu, maka terkadang menjadikan kelengkapan dokumen tersebut terabaikan.

Seharusnya permasalahan tingkat serapan anggaran tersebut dapat ditekan jika instansi pemerintah dapat konsisten membelanjakan anggarannya sesuai dengan target yang telah ditetapkan demi terwujudnya manajemen kas yang baik. Sebagaimana diatur dalam Peraturan Menteri Dalam Negeri Nomor 13 Tahun 2006 tentang Pedoman Pengelolaan Keuangan Daerah, setiap instansi pemerintah daerah diwajibkan menyusun dan menetapkan anggaran kas yang berguna sebagai pengendali arus kas masuk dan keluar serta berfungsi sebagai target serapan anggaran. Ini diharapkan untuk proses pelaksanaan pembangunan dan pencairan anggaran seharusnya dapat berlangsung tepat waktu, lebih merata dan memberikan dampak yang berulang dan besar kepada kegiatan perekonomian.

Berdasarkan pemaparan uraian diatas peneliti mencoba mengembangkan argumentasi bahwa untuk dapat memahami fenomena tentang penyebab rendahnya penyerapan anggaran diawal tahun anggaran berjalan pada Pemerintah Provinsi Nusa Tenggara Barat maka harus dilakukan pendekatan penelitian yang mendalam pada tingkat Satuan Kerja Perangkat Daerah (SKPD). Hal ini karena pada entitas inilah tanggungjawab pengelolaan anggaran berada mulai dari perencanaan, pelaksanaan, pelaporan sampai dengan pertanggungjawaban anggaran.

Beberapa studi yang membahas masalah rendahnya penyerapan anggaran pada tingkat SKPD seperti Rozai dan Subagiyo (2015) yang melakukan penelitian pada Inspektorat Kabupaten Boyolali. Saridewi et al. (2013) yang meneliti topik yang sama pada Dinas Pekerjaan Umum Kota Denpasar. Satuan Kerja Perangkat Daerah (SKPD) yang berperan sebagai stakeholders pemerintah daerah berperan penting untuk memajukan suatu daerah karena pemerintah diharapkan mampu melaksanakan pembangunan secara maksimal. Suatu daerah dapat dikategorikan maju bisa dilihat dari peran pemerintah selaku pemegang kekuasaan tertinggi suatu daerah yang mampu mengelola anggaran yang ada untuk kepentingan masyarakat. Kepentingan masyarakat yang dimaksud adalah bagaimana anggaran yang telah disahkan merupakan representasi dari apa yang diinginkan oleh masyarakat yang hasilnya nanti akan dinikmati oleh masyarakat itu sendiri. Hal tersebut dapat tercermin dari penyerapan anggaran yang efektif dan efisien hasilnya sesuai dengan yang diharapkan.

Sedangkan penelitian yang dilakukan oleh Arif (2011) pada lingkup yang lebih luas di Provinsi Riau memberikan kesimpulan bahwasanya masing-masing daerah kabupaten/kota di Provinsi Riau memiliki faktor-faktor yang berbeda-beda yang mengakibatkan minimnya penyerapan APBD. Walaupun ada sebagian kecil faktor yang hampir sama namun memiliki karakteristik faktor yang berbeda. Faktor kapasitas SDM, faktor regulasi, faktor tender/lelang dan faktor lambannya pengesahan APBD masih merupakan faktor yang mendominasi minimnya penyerapan APBD. 
Berbeda dengan beberapa penelitian sebelumnya, penelitian ini lebih fokus untuk mengeksplorasi penyebab rendahnya penyerapan anggaran diawal tahun anggaran pada tingkat SKPD dan menarik kesimpulan tentang fenomena yang terjadi pada SKPD yang diteliti yaitu pada Biro Umum Setda Provinsi NTB. Adapun pemilihan lokasi penelitian pada Biro Umum Setda Provinsi NTB dengan alasan Biro Umum Setda Provinsi NTB adalah salah satu SKPD di Provinsi Nusa Tenggara Barat yang memiliki tugas pokok dan fungsi cukup kompleks terhadap hubungannya dengan pelayanan seperti Kepala Daerah dan Pimpinan Daerah, SKPD lain, Lembaga Teknis Daerah, Lembaga Non Pemerintah/BUMN/ BUMD dan terhadap masyarakat sehingga permasalahan dan kendala yang dihadapi terutama dalam pengelolaan anggaran juga cukup kompleks. Kemudian, Biro Umum Setda Provinsi NTB memiliki karakteristik penyerapan anggaran yang terjadi setidaknya pada 3 (tiga) tahun terakhir mulai dari 2013-2015 menunjukkan pola penyerapan anggaran yang rendah pada awal tahun anggaran atau semester pertama (triwulan I dan II), namun kemudian mengalami peningkatan menjelang berakhirnya tahun anggaran. Karakteristik belanja pada Biro Umum Setda Provinsi NTB mencakup semua jenis belanja yang ada seperti belanja pegawai, belanja barang/jasa dan belanja modal juga menjadi pertimbangan.

Fokus penelitian ini adalah mengidentifikasi faktor-faktor apa saja yang menjadi penyebab masih rendahnya serapan APBD terutama pada awal tahun anggaran atau semester pertama pada Biro Umum Setda Provinsi NTB. Tujuan penelitian ini adalah untuk mengidentifikasi faktor-faktor penyebab rendahnya penyerapan anggaran SKPD diawal tahun anggaran atau semester pertama tahun anggaran pada Biro Umum Setda Provinsi NTB. Secara teoritis kontribusi penelitian ini dapat dilihat dari penerapan teori birokrasi karena proses pengelolaan keuangan pada SKPD mulai dari perencanaan, pelaksanaan, pertanggungjawaban sampai pada pelaporan diatur dan dikendalikan oleh proses birokrasi sesuai dengan peraturan perundang-undangan yang berlaku. Sedangkan kontribusi praktis dapat digunakan sebagai sumbangsih pemikiran dan kontribusi nyata kepada para pengambil kebijakan/keputusan ditingkat SKPD, sehingga dapat mengantisipasi sedini mungkin hal-hal yang dianggap menghambat realisasi anggaran dan dapat segera mengambil kebijakan/keputusan tentang pengelolaan keuangan agar penyerapan anggaran dapat berjalan sesuai dengan target dan mampu merepresentasikan fungsi anggaran sebagai pendorong pertumbuhan ekonomi.

\section{TINJAUAN LITERATUR DAN FOKUS PENELITIAN}

\section{Anggaran Pendapatan dan Belanja Daerah}

Anggaran Pendapatan dan Belanja Daerah merupakan suatu rencana keuangan tahunan daerah yang ditetapkan berdasarkan peraturan daerah tentang APBD yang disetujui oleh Dewan Perwakilan Rakyat Daerah (Arif, 2011). Untuk menetapkan anggaran pendapatan daerah yang akuntabel dan transparan, dibutuhkan pengelolaan suatu sistem manajemen keuangan yang jelas dan berdaya guna. Jika disederhanakan ada beberapa siklus utama dalam pengelolaan keuangan di daerah, yakni: (1) perencanaan, (2) pelaksanaan, dan (3) pengendalian.

Pada tahap perencanaan, input yang digunakan adalah dari aspirasi masyarakat melalui Musrenbang yang dilakukan oleh Dewan Per-wakilan Rakyat Daerah (DPRD) dan Pemerintah Daerah, sebagai cikal bakal keterlibatan masyarakat dalam penetapan kebijakan strategis dalam penetapan anggaran pendapatan dan belanja daerah (Yuwono, 2008). Pada tahap pelaksanaan, setelah APBD ditetapkan, nanti seluruh kegiatan pelaksanaan akan dicatat melalui sistem akuntansi untuk menghasilkan laporan pelaksanaan APBD dan pertanggung jawaban kepada kepala daerah (Yuwono, 2008). Selanjutnya Yuwono (2008) menjelaskan pada tahap pengendalian, laporan pertanggung jawaban kepala daerah diserahkan kepada DPRD, proses evaluasi laporan pertanggung jawaban, serta keputusan evaluasi berupa penolakan atau penerimaan pertanggung jawaban kepala daerah.

\section{Penyerapan Anggaran}

Penyerapan anggaran merupakan salah satu tahapan dari siklus anggaran yang dimulai dari perencanaan anggaran, penetapan dan pengesahan anggaran oleh Dewan Perwakilan Rakyat (DPR), penyerapan anggaran, pengawasan anggaran dan pertanggungjawaban penyerapan anggaran (Kuncoro, 2013). Tahapan penyerapan anggaran ini dimulai ketika Undang-Undang (UU) Anggaran Pendapatan dan Belanja Negara (APBN) disahkan oleh DPR. Dalam rangka terjadinya 
kesatuan pemahaman serta kesatuan langkah dalam pelaksanaan, pemerintah sebagai pelaksana dari Undang-Undang APBN selanjutnya menerbitkan Keputusan Presiden (Keppres) tentang Pedoman Pelaksanaan Anggaran Pendapatan dan Belanja Negara sebagai dasar hukum pelaksanaan APBN. Pada saat ini Keppres yang berlaku adalah Keppres nomor 42 tahun 2002 (Kuncoro, 2013).

Begitu pula yang berlaku didaerah, penetapan dan pengesahan anggaran dilaksanakan oleh DPRD Provinsi dan Kabupaten/Kota. Selanjutnya tahapan penyerapan ini dimulai ketika Peraturan Daerah (Perda) tentang APBD disahkan oleh DPRD. Dalam rangka terjadinya persamaan langkah dan pemahaman pelaksanaan, pemerintah sebagai pelaksana Perda APBD menerbitkan Peraturan Gubernur (Pergub)/ Peraturan Bupati/ Wali Kota tentang Pedoman Pelaksanaan Anggaran Pendapatan dan Belanja Daerah sebagai dasar hukum pelaksanaan APBD.

Penyerapan anggaran, khususnya belanja barang dan jasa, memiliki pengaruh yang cukup signifikan dalam mendorong pertumbuhan ekonomi. Untuk itu setiap instansi pemerintah harus mengatur pengeluarannya agar berjalan lancar dan dapat mendukung keberhasilan pencapaian sasaran pembangunan nasional. Namun demikian penyerapan anggaran tidak diharuskan mencapai $100 \%$, tetapi penyerapan anggaran diharapkan mampu memenuhi setidak-tidaknya lebih dari $80 \%$ anggaran yang telah ditetapkan. Tinggi rendahnya penyerapan anggaran dalam suatu SKPD menjadi tolok ukur kinerja dari SKPD tersebut.

Akan tetapi, SKPD belum mampu konsisten dalam hal penyerapan anggaran sesuai dengan target yang telah ditetapkan dari segi jumlah penyerapan anggaran maupun waktu pelaksanaannya. Penyerapan anggaran SKPD cenderung rendah diawal tahun anggaran dan akan mulai meningkat secara signifikan menjelang akhir tahun anggaran. Hal ini menjadi pertanyaan peneliti, halhal apa saja yang menyebabkan rendahnya penyerapan anggaran pada SKPD yang menyebabkan masih rendahnya penyerapan APBD khususnya pada semester pertama tahun anggaran.

\section{METODE PENELITIAN}

\section{Pendekatan Penelitian}

Jenis penelitian yang digunakan dalam penelitian ini adalah penelitian kualitatif, dimana penelitian kualitatif menganggap segala sesuatu yang melibatkan manusia akan bersifat kompleks dan multidimensi, apalagi jika melibatkan sekelompok manusia dan interaksinya, kompleksitas tersebut akan sangat sulit diukur dengan angkaangka statistik (Sarosa, 2012:9). Penelitian kualitatif berusaha memahami kompleksitas fenomena yang diteliti dimana peneliti berusaha untuk menginterpretasikan suatu fenomena dan memahami suatu fenomena dari sudut pandang pelaku didalamnya.

Untuk mendapatkan pemahaman yang mendalam maka fenomena ini dikaji dengan menggunakan pendekatan wawancara yang berfokus pada individu/aktor yang terlibat pada suatu kasus atau fenomena yang terjadi. Individu/aktor ini dianggap paling tahu tentang apa yang kita harapkan, atau mungkin sebagai penguasa sehingga akan memudahkan peneliti mencari penyebab fenomena yang terjadi pada awal tahun anggaran, mengapa pada awal tahun anggaran tersebut penyerapan anggaran cenderung sangat rendah (Latuconsina, 2016). Penelitian kualitatif dianggap tepat digunakan dalam penelitian ini karena eksplorasi fenomena dapat digali secara langsung dan mendalam dengan berinteraksi dengan aktor, daripada dilakukan secara empiris, misalnya dengan pengujian hipotesis secara statistik.

\section{Sumber Data}

Sumber data yang digunakan dalam penelitian ini digolongkan menjadi dua, yaitu data primer dan data sekunder yang langsung diperoleh dari sumber informasi. Data primer dalam penelitian ini diperoleh dari hasil wawancara yang dilakukan dengan para stakeholder yang relevan pada Biro Umum Setda Provinsi NTB yang berhubungan langsung dengan penyerapan anggaran. Data sekunder dalam penelitian ini diperoleh dari hasil telaah dokumen yang berisi informasi yang berhubungan dengan penyerapan anggaran pada Biro Umum Setda Provinsi NTB serta peraturan-peraturan yang berkaitan dengan tujuan penelitian.

\section{Informan dan Lokasi}

Agar mendapatkan pemahaman yang mendalam terhadap fenomena yang menjadi objek penelitian, penentuan informan menggunakan teknik snowball sampling, yakni teknik pengambilan sampel yang pada awalnya sedikit, lama-lama menjadi besar (Sugiyono, 2015). Informan kunci 
dalam penelitian ini adalah Pejabat Penatausahaan Keuangan Satuan Kerja Perangkat Daerah (PPKSKPD).

PPK-SKPD merupakan pihak yang ditunjuk oleh Kuasa Pengguna Anggaran (KPA) untuk membuat keputusan dan/atau mengambil tindakan yang dapat mengakibatkan pengeluaran anggaran belanja yang ditetapkan dengan Surat Keputusan (SK) KPA. PPK-SKPD merupakan individu/aktor yang memiliki hubungan yang sangat erat dengan baik/buruknya penyerapan anggaran disuatu SKPD. Ini dapat dilihat dari tugas PPKSKPD tersebut sesuai dengan surat keputusan. Adapun lokasi penelitian adalah bertempat pada Biro Umum Setda Provinsi NTB

\section{Analisis Data}

Analisis data ini menggunakan pendekatan kualitatif secara interaktif dan berlangsung secara terus menerus sampai tuntas, sampai datanya sudah jenuh, aktivitas dalam menganalisis data meliputi: reduksi data (reduction data), penyajian data (display data), menarik kesimpulan atau verifikasi (concluncing drawing) (Sugiyono, 2014).

\section{HASIL DAN PEMBAHASAN}

Berdasarkan Peraturan Daerah Provinsi Nusa Tenggara Barat Nomor 11 Tahun 2014 tentang Perubahan Kedua atas Peraturan Daerah Provinsi Nusa Tenggara Barat Nomor 6 Tahun 2008 tentang Organisasi dan Tata Kerja Sekretariat Daerah Provinsi Nusa Tenggara Barat dan Sekretariat Dewan Perwakilan Rakyat Daerah Provinsi Nusa Tenggara Barat. Biro Umum Komplementer dari Sekretariat Daerah Provinsi Nusa Tenggara Barat. Dimana Biro Umum merupakan 1 (satu) dari 9 (sembilan) Biro pada Sekretariat Daerah yang berada dibawah koordinasi Asisten Administrasi Umum dan Kesejahteraan (Asisten III Sekda), terdiri dari 4 (Empat) Bagian dan 12 (Dua Belas) Sub Bagian.

Biro Umum Setda Provinsi NTB merupakan salah satu unit kerja pendukung (supporting unit) dan unit koordinator (coordinating unit) dalam memberikan pelayanan kepada Pimpinan dalam pelaksanaan tugas Pemerintahan. Salah satu unsur yang paling penting dalam organisasi adalah Sumber Daya Manusia (SDM) atau pegawai yang akan menggerakkan dan melaksankan tugas organisasi. Untuk menunjang pelaksanaan tugas pokok dan fungsi Biro Umum Sekretariat Daerah
Provinsi Nusa Tenggara Barat, didukung oleh 177 (seratus tujuh puluh tujuh) orang Pegawai Negeri Sipil, dan 8 (delapan) orang Pegawai Tidak Tetap (PTT).

Adapun tugas pokok dari Biro Umum Setda Provinsi NTB adalah "Menyiapkan perumusan kebijakan, pembinaan, kooordinasi, dan evaluasi penyelenggaraan kesekretariatan dan pengolahan data elektronik, rumah tangga, keuangan dan urusan dalam”. Sedangkan fungsi dari Biro Umum Setda Provinsi NTB adalah : (1) Perumusan dan penyiapan pembinaan penyelenggaraan kesekretariatan dan pengolahan data elektronik, Pembinaan LPSE, rumah tangga, keuangan serta urusan dalam, (2) Perumusan dan penyusunan rencana/program dibidang kesekretariatan dan pengolahan data elektronik, Pembinaan LPSE, rumah tangga, keuangan serta urusan dalam, (3) Perumusan kebijakan penyelenggaraan dibidang kesekretariatan dan pengolahan data elektronik, Pembinaan LPSE, rumah tangga, keuangan serta urusan dalam, (4) Koordinasi pelaksanaan tugas dibidang kesekretariatan dan pengolahan data elektronik, Pembinaan LPSE, rumah tangga, keuangan serta urusan dalam, (5) Evaluasi dan pelaporan pelaksanaan tugas dibidang kesekretariatan dan pengolahan data elektronik, rumah tangga, keuangan dan urusan dalam, (6) Pelaksannaan tugas kedinasan lain yang diberikan pimpinan sesuai dengan bidang tugas.

Sesuai dengan tujuan penelitian untuk mengidentifikasi faktor-faktor penyebab rendahnya penyerapan anggaran pada Biro Umum Setda Provinsi NTB disemester pertama tahun anggaran, dan juga telah dibahas sebelumnya mengenai informan kunci pada penelitian ini adalah Pejabat Penatausahaan Keuangan (PPK-SKPD), maka untuk mendapatkan informasi yang lebih mendalam sesuai dengan teknik penentuan informan dengan teknik snowball sampling, namun para pejabat pengelola keuangan lainnya dapat juga dijadikan informan dalam penelitian ini tentunya sesuai dengan arahan dari informan kunci.

\section{Target dan Realisasi Anggaran Biro Umum Sekretariat Daerah Provinsi NTB}

Biro Umum Setda Provinsi NTB memiliki karakteristik penyerapan anggaran yang terjadi selama 3 (tiga) tahun terakhir mulai dari tahun 2013-2015 yang menunjukkan pola penyerapan anggaran yang rendah pada awal tahun anggaran atau semester pertama (triwulan I dan II) kemudian mengalami peningkatan menjelang ber- 
Tabel 1. Data penyerapan anggaran semester I tahun 2013-2015 pada Biro Umum Sekretariat Daerah Provinsi NTB

\begin{tabular}{ccccrc}
\hline \multirow{2}{*}{ No. } & $\begin{array}{c}\text { Tahun } \\
\text { Anggaran }\end{array}$ & $\begin{array}{c}\text { Pagu } \\
\text { Anggaran (Rp) }\end{array}$ & $\begin{array}{c}\text { Target } \\
\text { Semester I (Rp) }\end{array}$ & $\begin{array}{c}\text { Penyerapan Anggaran } \\
\text { (Rp) }\end{array}$ & \multirow{2}{*}{ \% } \\
\hline 1 & 2013 & 88.710 .317 .000 & 45.551 .912 .725 & 29.934 .697 .14 & 33,74 \\
2 & 2014 & 107.720 .823 .200 & 55.131 .574 .675 & 31.513 .611 .571 & 29,25 \\
3 & 2015 & 113.667 .717 .492 & 56.833 .858 .746 & 37.480 .469 .708 & 32,98 \\
\hline
\end{tabular}

Sumber : Bagian Keuangan Biro Umum NTB

akhirnya tahun anggaran. Menurut data yang diperoleh, realisasi penyerapan anggaran pada Biro Umum Setda Provinsi NTB dalam tiga tahun terakhir pada semester pertama tahun anggaran rata-rata penyerapannya tidak sesuai target yang telah ditetapkan yaitu sebesar 50 \% dari total APBD yang dikelola oleh Biro Umum Setda Provinsi NTB. Pada Tabel 1 disajikan data serapan anggaran semester pertama pada Biro Umum Setda Provinsi NTB tahun 2013-2015.

Dari Tabel 1 dapat dilihat bahwa penyerapan anggaran semester pertama pada Biro Umum Setda Provinsi NTBhanya rata-rata sekitar 30 \%masih jauh dari target yang telah ditetapkan yaitu sebesar $50 \%$. Tentu ini menjadi suatu hal yang kurang baik, karena penyerapan anggaran pada awal tahun anggaran tersebut lebih banyak pada belanja tidak langsung seperti gaji dan tunjangan PNS yang memang sifatnya rutin. Sedangkan untuk belanja yang sifatnya belanja barang/jasa tidak terlalu signifikan realisasinya, seperti yang disampaikan oleh PPK-SKPD ketika disinggung peneliti mengenai permasalahan yang sama dari tahun ke tahun.

\footnotetext{
“...Pada awal tahun anggaran, penyerapan anggaran itu lebih banyak pada belanja yang sifatnya rutin seperti gaji atau tunjangantunjangan lainnya, di Pemerintah Provinsi ada TKD-nya, itu yang sifatnya rutin, karena untuk pembayaran gaji dan tunjangan tidak memerlukan regulasi-regulasi tambahan karena itu sudah berjalan otomatis, maksudnya regulasinya tidak banyak berubah”.
}

Selain penyerapan anggaran pada belanja tidak langsung tersebut, ada juga penyerapan anggaran pada belanja langsung tetapi sama halnya dengan belanja tidak langsung hanya pembayaran yang sifatnya rutin saja dan tidak membutuhkan banyak regulasi tetapi harus tetap dibayarkan contohnya seperti pembayaran listrik, telpon dan air. Pembayaran listrik, telpon dan air tersebut juga tidak bisa diprediksi jumlah besarannya karena tergantung dari intensitas penggunaannya. Hal ini diperkuat dengan pernyataan yang disampaikan juga oleh PPK-SKPD ketika peneliti menanyakan ada serapan lain selain belanja tidak langsung yang sifatnya rutin pada awal tahun anggaran.

“...tapi ada beberapa komponen belanja
barang yang juga bersifat rutin tetapi tetap
harus dibayarkan. Ada beberapa yang tidak
bisa diestimasi juga, karena itu tergantung dari
intensitas pekerjaannya contohnya seperti
belanja listrik, air dan telpon, dan ini sifatnya
yang fluktuatif, masing-masing bulan otomatis
berbeda tagihannya, pada saat banyak kegiatan
terkadang jumlah tagihan terhadap listrik akan
meningkat”.

Kedua pernyataan dari PPK-SKPD tersebut dibenarkan juga oleh Bendahara Pengeluaran pada Biro Umum Setda Provinsi NTB sebagai pejabat pengelolaan keuangan yang bertanggungjawab terhadap pengeluaran kas.
“...Kalau untuk yang awal-awal, biasanya memang kita itu lebih ke belanja rutin misal seperti gaji atau tunjangan yang memang sudah ada, istilahnya SK atau kebijakannya sudah ada, ataupun belanja-belanja kantor, listrik, air, telpon. Kalau untuk pengadaan biasanya ada kebijakan tersendiri, mungkin ada jadwal juga, itu juga yang membuat serapan diawal itu agak rendah".

Tingkat serapan anggaran yang cenderung rendah diawal tahun adalah situasi yang mem-berikan dampak adanya penumpukan anggaran yang belum dilaksanakan menjelang akhir tahun. Hal ini merupakan suatu akibat dari pelaksanaan kegiatan yang belum berjalan optimal. Pelaksanaan kegiatan yang tidak berjalan optimal tersebut menyebabkan inkonsistensi SKPD dalam melaksanakan kegiatan sesuai dengan target yang telah ditetapkan. Tentu ini menjadi suatu hal yang kurang baik, karena penyerapan anggaran saat ini menjadi tolok ukur penilaian kinerja suatu SKPD karena pengukuran kinerja dilakukan dengan membandingkan target dan realisasi. Karena 
kejadian ini sudah sering terjadi bahkan berulangulang setiap tahunnya ini bisa dikatakan sebagai budaya organisasi karena kejadiannya terus berulang.

Kegiatan-kegiatan yang seharusnya bisa dilaksanakan diawal-awal tahun lebih banyak dilaksanakan menjelang akhir tahun sehingga kesannya cenderung dipaksakan. Karena kesannya cenderung dipaksakan, dalam proses pengajuan dokumen SPJ rawan terjadi kesalahan karena cenderung mengabaikan aturan yang ada baik dari segi proses dan kelengkapannya. Oleh karena itu, peneliti mencoba menarik kesimpulan secara umum tentang penyebab rendahnya penyerapan anggaran diawal tahun anggaran yang mempengaruhi tingkat serapan anggaran pada Biro Umum Setda Provinsi NTB berdasarkan hasil wawancara terhadap informan selama melakukan penelitian. Berdasarkan hasil wawancara tersebut peneliti mengklasifikasikan faktor-faktor tersebut kedalam tiga faktor.

\section{Faktor Sumber Daya Manusia (SDM)}

Keberadaan manusia dalam organisasi memiliki posisi yang sangat vital. Keberhasilan organisasi sangat ditentukan oleh kualitas orang-orang yang bekerja di dalamnya. SDM sangat berperan penting untuk mencapai tujuan dari organisasi. SDM merupakan aset dari organisasi yang dapat menentukan baik buruknya kinerja dari sebuah organisasi. Bisa dikatakan hampir semua persoalan yang dihadapi oleh suatu organisasi selalu terkait dengan SDM yang ada di dalamnya. Begitu juga pada Biro Umum Setda Provinsi NTB sebagai sebuah SKPD, layaknya seperti organisasi pada umumnya Biro Umum Setda Provinsi NTB juga memiliki permasalahan yang sama dengan organisasi lain terkait SDM terutama terkait dengan pengelolaan keuangan yang dapat mempengaruhi tingkat serapan anggaran yang rendah pada awal tahun anggaran. Pernyataan tersebut sesuai keterangan yang dikatakan oleh PPK-SKPD ketika peneliti menanyakan penyebab dari fenomena yang terjadi.

\footnotetext{
“...Tidak semua pejabat pengelola keuangan itu paham terhadap aturan-aturan dalam mengelola keuangan, sehingga inilah yang menyebabkan terkadang penyerapan anggaran itu menjadi lambat.Salah satu contohnya dalam mengadakan barang dan jasa pemerintah, kita punya aturan berupa Perpres, yang terbaru adalah Perpres 4 tahun 2015, jadi
}

seharusnya semua PPTK, semua pengelola kegiatan harus paham terhadap aturan ini, tetapi karena ada pejabat pengelola keuangan yang diangkat berdasarkan jabatannya sehingga itu yang menyebabkan kekurangtahuan pengetahuannya itu tidak diimbangi dengan penambahan pengetahuan. Dengan menyandang sebagai pejabat pengelolaan keuangan seharusnya mereka juga menambah pengetahuan terhadap aturan-aturan pengelolaan keuangan".

Berdasarkan petikan wawancara tersebut dapat dikatakan bahwa ternyata ada pejabat pengelola keuangan yang memang kurang paham terkait pengelolaan keuangan. Ini disebabkan karena ada pejabat struktural yang secara otomatis juga menjadi pejabat pengelola keuangan karena menjadi pejabat pengelola keuangan tersebut juga melekat pada tugas dan fungsinya sebagai pejabat struktural tersebut contohnya Pengguna Anggaran (PA), Kuasa Pengguna Anggaran (KPA) dan Pejabat Pelaksana Teknis Kegiatan (PPTK). Sehingga bisa disimpulkan bahwa seseorang paham atau tidak terhadap pengelolaan keuangan tetapi jika seseorang tersebut diangkat menjadi pejabat struktural yang otomatis menjadi PA, KPA dan PPTK maka bertanggungjawab terhadap pengelolaan keuangan sesuai dengan tugas dan fungsinya masing-masing. Ini dipertegas oleh PPKSKPD ketika disinggung oleh peneliti mengenai kriteria-kriteria penunjukan pejabat pengelola keuangan.

“...Selain itu juga tadi ada jelaskan bahwa peja-
bat pengelola keuangan berdasarkan jabatan
yang dimilki sekarang, itu terkait dengan
pejabat struktural contohnya ada PA, KPA
kemudian ada PPTK. Beberapa jabatan itu
dimiliki oleh seseorang berdasarkan jabatan
struktural yang dimiliki. Di Biro Umum ini
Kepala Biro itu selaku KPA, siapapun Kepala
Bironya, punya sertifikat (Pengadaan barang/
jasa) atau tidak, mau paham keuangan mau
tidak, otomatis akan menjadi KPA. Itu adalah
beberapa kriteria-kriteria dasar yang terkait
dengan pejabat pengelola keuangan”.

Pada dasarnya pejabat pengelolan keuangan tersebut dibagi menjadi dua kategori, ada pejabat pengelola keuangan yang dibahas sebelumnya yang secara otomatis melekat langsung pada jabatan strukturalnya dan ada pula yang ditunjuk berdasarkan kemampuan dan pengetahuan yang dimiliki. Contohnya seperti Pejabat Pembuat Komitmen (PPK) dan Pejabat Pengadaan Barang/ 
Jasa Pemerintah. Mengenai hal tersebut PPKSKPD juga memberikan komentar yang dikutip oleh peneliti.

\begin{abstract}
“...Terkait pejabat pengelola keuangan ada beberapa kriteria. Ada pejabat pengelolaan keuangan yang memang di dasarkan terhadap kemampuan atau pengetahuan yang dimiliki dan ada juga yang melekat dengan jabatan. Untuk pejabat pengelola keuangan yang berdasarkan pengetahuan yang dimiliki salah satu contohnya adalah pejabat pengadaan, pejabat pengadaan ini ditunjuk adalah orang yang memiliki sertifikat pengadaan barang dan jasa tingkat nasional. Begitu juga PPK (Pejabat Pembuat Komitmen), harus memiliki sertifikat pengadaan barang dan jasa pemerintah yang syarat minimalnya adalah dua tahun menjadi pejabat pengadaan”.
\end{abstract}

PPK dan Pejabat Pengadaan Barang/Jasa adalah pejabat yang ditunjuk untuk melaksanakan kegiatan pengadaan barang/jasa pemerintah dan tentunya harus memiliki sertifikat pengadaan barang/jasa. Untuk mendapatkan sertifikat pengadaan barang/jasa tersebut tentunya harus mengikuti ujian sertifikasi pengadaan barang/jasa pemerintah dan dinyatakan lulus oleh Lembaga Kebijakan Pengadaan barang/jasa Pemerintah (LKPP). Jika memiliki sertifikat pengadaan barang/jasa tersebut seseorang sudah dianggap mampu dan mengetahui seluk beluk pengadaan barang/jasa, maka dianggap layak untuk ditunjuk sebagai pejabat yang menangani kegiatan pengadaan barang/jasa.

Berbeda halnya dengan pejabat pengelola keuangan yang secara otomatis melekat pada jabatan strukturalnya, pejabat ini tidak memiliki kriteria khusus sebagai pengelola keuangan dan juga terkadang tidak memiliki sertifikat pengadaan barang/jasa sehingga diindikasikan banyak dari pejabat tersebut kurang paham terhadap pengelolaan keuangan dan mekanisme pengadaan barang/ jasa. Padahal usulan pertama untuk perencanaan pengadaan itu letaknya pada pejabat tersebut contohnya Pejabat Pelaksana Teknis Kegiatan (PPTK) yang juga dapat dikatakan sebagai pengelola kegiatan dan pengelola anggaran.

Hal seperti inilah yang terjadi pada Biro Umum Setda Provinsi NTB sehingga permasalahan mengenai kompetensi SDM ini menjadi salah satu faktor yang mempengaruhi tingkat serapan anggaran pada SKPD ini. Kompetensi SDM ini menjadi penting untuk ditingkatkan karena dalam pelaksanaan pengelolaan keuangan ini diperlukan pemahaman dan persepsi yang sama terhadap aturan yang berlaku. Ketika seorang pejabat kurang paham terhadap pengelolaan keuangan sementara pejabat tersebut sebagai penanggungjawab dari kegiatan tersebut tentunya ini menjadi sesuatu yang kurang baik karena akan memperlambat proses realisasi anggaran yang dikarenakan kurangnya pemahaman pejabat tersebut terhadap pengelolaan keuangan. Untuk mendapatkan kesamaan persepsi sebenarnya pejabat struktural itu penting menguasai mekanisme pengelolaan keuangan dan sistematika pengadaan barang/jasa tetapi tidak wajib bersertifikat. Hal ini cukup dengan mengikuti bimbingan teknis (Bintek) saja, karena ini untuk menyamakan pemahaman dan persepsi tersebut.

\section{Faktor Administrasi}

Pada awal tahun anggaran SKPD biasanya disibukkan dengan persiapan-persiapan administrasi untuk pelaksanaan kegiatan seperti penerbitan Surat Keputusan (SK) sebagai payung hukum untuk pelaksanaan kegiatan selama satu tahun kedepan pada SKPD. Akan tetapi juga terdapat pekerjaan yang seyogyanya harus sudah selesai pada tahun sebelumnya tetapi dikarenakan ada kesalahan-kesalahan sehingga harus disesuaikan kembali pada awal tahun anggaran berjalan, sehingga SKPD tidak dapat menjalankan aktifitas pelaksanaan kegiatannya secara efektif pada awal tahun.

Menurut Permendagri Nomor 13 Tahun 2006, proses pengelolaan keuangan daerah itu sudah diatur secara detail mulai dari perencanaan, pelaksanaan dan pertanggungjawaban, evaluasi dan pelaporan. Khusus untuk proses perencanaan pada Biro Umum Setda Provinsi NTB ini masih sering terjadi permasalahan terkait penyusunan rencana kerja anggaran (RKA), ini diungkapkan oleh PPK-SKPD dalam wawancara ketika ditanyakan tentang permasalahan penyusunan dokumen perencanaan.

“...Dalam setiap proses perencanaan pasti ada masalahnya, karena banyak bagian-bagian atau PPTK ini terkadang dalam mengajukan perencanaan itu tidak didalam bentuk RKA, hanya berupa kegiatan-kegiatan yang akan dilaksanakan tetapi rincian kegiatannya itu tidak diberikan. Jadi daftar kebutuhan belanja itu terkadang sering berubah-ubah”.

Terlepas dari permasalahan tersebut, Pemerintah Provinsi NTB dalam hal proses perenca- 
naan anggaran sudah jauh lebih baik dibandingkan pada waktu sebelumnya. Penetapan Anggaran Pendapatan dan Belanja Daerah (APBD) untuk tahun berikutnya sudah ditetapkan dan disahkan pada akhir tahun sebelumnya. Ini diharapkan agar pada awal tahun anggaran berikunya seluruh kegiatan pelaksanaan APBD sudah dapat langsung dilaksanakan tepat pada bulan januari. Berdasarkan hasil wawancara dengan PPK-SKPD hal ini dijelaskan kepada peneliti.

“...jadi pada era kepemimpinan Gubernur kita yang sekarang ini ada perubahan-perubahan atau perbaikan-perbaikan dari apa yang dilaksanakan pada era-era sebelumnya. Jadi pada era Gubernur yang sekarang ini APBD itu ditetapkan pada akhir tahun anggaran sebelumnya. Jadi misalkan untuk anggaran 2017 itu harus ditetapkan pada akhir tahun anggaran 2016, dan itu juga sama dengan regulasi yang ditetapkan oleh pusat bahwa sebelum 30 november harus sudah menetapkan APBD untuk tahun berikutnya. Itu adalah regulasi-regulasi yang mungkin tetap diperbaharui dalam rangka meningkatkan penyerapan anggaran yang kaitannya nanti diharapkan dapat membantu perkembangan perekonomian pada masyarakat”.

Output dari seluruh proses perencanaan itu menghasilkan dokumen pelaksanaan anggaran (DPA) yang digunakan sebagai acuan dalam pelaksanaan anggaran. Tetapi pada pelaksanaannya DPA yang sudah ditetapkan dan disahkan sebelum tahun anggaran berjalan terkadang pada waktu pelaksanakan masih sering dijumpai kesalahan. Kesalahan-kesalahan yang sering dijumpai antara lain adalah kesalahan penulisan seperti salah ketik, salah volume, salah redaksi dan lainlain. Jika terjadi demikian kita harus melakukan revisi DPA, revisi DPA harus dilakukan karena jika dokumen perencanaannya salah akan mempengaruhi pada proses pertanggungjawabannya. Hal ini disampaikan oleh PPK pada saat wawancara.

“...Kemudian juga revisi DPA tentu ada pengaruh-pengaruhnya karena ada koreksikoreksi walaupun sudah ada ini [Pengesahan DPA] tetap ada koreksi-koreksi DPA. Kemudian, walaupun DPA itu sudah ditetapkan tetapi proses-proses untuk pencairannya itu aja yang keliru-keliru. Misalnya salah ketik, salah redaksi, salah volume, itumempengaruhi juga, kalau keliru itu juga ndak bisa di-SPJkan”.
Biro Umum Setda Provinsi NTB sesuai tugas dan fungsinya sebagian besar sebagai pelayanan terhadap pimpinan daerah, tentunya revisi DPA tersebut ada juga yang disebabkan karena ada permintaan atau kebijakan dari pimpinan terkait pelayanan tersebut. Bisa dikatakan penyusunan perencanaan kegiatan pada Biro Biro Umum Setda Provinsi NTB sebagian besar adalah buy request dari pimpinan daerah dalam hal ini KDH/WKDH. Pernyataan ini sesuai dengan apa yang dikatakan oleh salah seorang PPTK pada Biro Umum Setda Provinsi NTB yang banyak melaksanakan kegiatan-kegiatan yang sifatnya pelayanan pimpinan.

“...Contoh dirumah tangga ini, sebagian besar kegiatannya berdasarkan buy request, karena ini pelayanan langsung kepada pimpinan KDH/WKDH. Ada beberapa kegiatan yang sudah kita rancang tapi ternyata dikemudian hari permintaan pimpinan berubah, sepanjang itu sesuai aturan dan kita bisa ada peluang, ada celah untuk revisi DPA ya kita ubah, tetapi tetap saja memang terasa pada penyerapan anggaran, tetapi tentunya sekali lagiini harus".

Hal tersebut juga dibenarkan oleh PPKSKPD ketika ditanyakan mengenai hal yang serupa pada saat wawancara. Berikut kutipan penjelasan PPK-SKPD:

“...Seperti saya katakan tadi, disini Biro Umum adalah Biro yang melayani pimpinan secara langsung, terkadang apa yang sudah kita rencanakan tapi ada permintaan atau kebijakan dari pimpinan sehingga apa yang kita rencanakan itu bisa berubah, itu yang harus kita lakukan revisi”.

Seperti yang dikatakan diawal, selain permasalahan mengenai dokumen perencanaan yang harus direvisi karena ada kesalahan-kesalahan dan juga permintaan atau kebijakan pimpinan sehingga berdampak pada serapan anggaran pada awal tahun anggaran, masalah lain adalah penerbitan SK penunjukan pejabat pengelolaan keuangan yang terlambat sehingga para pejabat yang ditunjuk sebagai pejabat pengelola keuangan belum bisa melaksanakan tugasnya karena SK tersebut merupakan payung hukum untuk melindungi pejabat-pejabat tersebut dari kesalahan-kesalahan 
yang bersifat administrasi, karena ini berkaitan dengan masalah regulasi dalam pelaksanaan kegiatan SKPD yang menganut azas legalitas. Ini senada dengan apa yang dikatakan oleh PPKSKPD saat disinggung masalah regulasi-regulasi yang berkaitan dengan pengelolaan keuangan.

“...Mengenai penerbitan SK juga seperti itu, jadi setiap pelaksanaan kegiatan harus ada payung hukumnya. SK merupakan payung hukum dalam menunjuk pejabat pengelolaan keuangan tersebut, tanpa SK tentunya kita tidak bisa bekerja, jadi kita harus menunggu SK, jadi terkadang dengan lambatnya turunnya SK juga mempengaruhi dalam keterlambatan dalam bekerja. Jadisaya rasa masalah SK, masalah regulasi-regulasi itu sangat mempengaruhi dalam pelaksanaan kegiatan”.

Penerbitan SK ini memang menjadi kendala jika pihak-pihak yang berwenang dalam menerbitkan SK ini terlambat menerbitkannya. Karena sesungguhnya pihak yang berwenang menerbitkan ini ada dari pihak eksternal dan ada pula dari pihak internal SKPD. SK yang berkaitan dengan penunjukan PA, KPA dan Bendahara Pengeluaran adalah SK yang diterbitkan oleh pihak eksternal karena ditandatangani oleh Gubernur. Sedangkan SK penunjukan yang ditandatangani oleh Kepala SKPD adalah SK penunjukan dari pihak internal, contohnya seperti SK penunjukan PPK-SKPD, PPK dan PPTK. Petikan wawancara dengan PPK berikut menggambarkan hal-hal tersebut.

“...Tapi kalau menurut saya kendalanya ada faktor eksternal dan internal. Eksternal ini terkait dengan contoh realnya masalah SK, SK pejabat pengelola keuangan seperti Bendahara, KPA, PAyang memang sangat tergantung pada BPKAD karena SK Gubernur. Kalau terkait dengan internalseharusnya hal-hal seperti ini bisa diantisipasi khususnya terkait dengan SK Kepala Biro contohnya untuk SK PPK, PPTK, dan sebagainya. Itu kendalanya kalau saya lihat. Kalau secara aturansangat memungkinkan, seharusnya sudah tidak ada alasan awal tahun itu realisasi mandek”.

Berdasarkan pernyataan-pernyataan informan tersebut dapat disimpulkan bahwa revisi dokumen perencanaan (DPA) dan terlambatnya penerbitan surat keputusan penunjukan pejabat pengelolaan keuangan sangat mempengaruhi pelaksanaan kegiatan pada Biro Umum Setda Provinsi NTB. Karena sifatnya administratif keduanya harus selesai terlebih dahulu sebelum melaksanakan kegiatan. Pelaksanaan kegiatan pada SKPD didasarkan pada DPA dan SK, jika kedua hal tersebut pengesahannya terlambat maka pelaksanaan kegiatannya juga akan terlambat memulainya. Inilah yang menyebabkan serapan anggaran pada Biro Umum Setda Provinsi NTB diawal tahun anggaran itu cenderung rendah karena harus menyelesaikan regulasi-regulasi yang bersifat administrasi tadi.

\section{Faktor Kebijakan}

Kebijakan identik dengan pengambilan keputusan oleh pemegang kekuasaan yang memiliki wewenang dan tanggung jawab yang besar dalam mengambil setiap keputusan. Pengambilan kebijakan yang telah diputuskan ini biasanya dilegalkan dalam bentuk surat keputusan dan surat edaran. Contohnya surat edaran mengenai pedoman penyusunan dokumen perencanaan, dalam surat edaran pedoman penyusunan dokumen perencanaan tersebut ditentukan kegiatan-kegiatan dan belanja-belanja apa saja yang boleh dianggarkan untuk dilaksanakan sesuai dengan kebutuhan.

Proses penyusunan dokumen perencanaan dimulai dengan penyusunan rencana kerja anggaran (RKA) sesuai dengan edaran pedoman penyusunan. Setelah seluruh proses penyusunan RKA rampung dan telah disetujui oleh tim anggaran pemerintah daerah (TAPD) barulah kemudian dokumen perencanaan tersebut diterbitkan dalam bentuk dokumen perencanaan anggaran (DPA). Untuk menerbitkan DPA, SKPD juga harus menyusun anggaran kas yang mengatur perkiraan arus kas keluar berdasarkan ketersediaan dana yang cukup guna mendanai pelaksanaan kegiatan dalam satu periode.

Anggaran kas besarannya disusun berdasarkan surat edaran dari Gubernur melalui BPKAD (Badan Pengelola Keuangan dan Aset Daerah) selaku pengelola keuangan daerah. Besaran persentase anggaran kas ditentukan oleh kebijakan kepala daerah, karena bersifat kebijakan tentunya besaran persentase anggaran kas tersebut berbedabeda disetiap daerah. Untuk di Provinsi NTB besaran persentase anggaran kas tersebut dibagi menjadi empat, sesuai dengan jumlah triwulan dalam satu tahun anggaran. Pada triwulan satu sebesar $20 \%$, triwulan kedua sebesar $30 \%$, triwulan ketiga sebesar $30 \%$ dan pada triwulan keempat sebesar $20 \%$ sehingga jumlahnya menjadi $100 \%$. Penyusunan dan besaran persen- 
tase anggaran kas ini juga disampaikan oleh PPKSKPD ketika peneliti menanyakan hal tersebut.

“...Anggaran kas itu adalah suatu kewajiban yang harus kita lakukan dalam proses perencanaan anggaran. Apabila kita tidak mengatur anggaran itu otomatis kita tidak bisa melaksanakan anggaran, karena itu adalah salah satu dasar atau syarat yang harus kita masukan dalam aplikasi SIMDA. Setelah kita masukan dalam SIMDA akan nanti tercetak didalam DPA. Di DPA itu akan terlihat anggaran kas masing-masing triwulan dimana triwulan pertama itu ada sebesar $20 \%$, triwulan dua dan tiga itu $30 \%$, dan triwulan empat itu besarannya $20 \%$, karena ini berdasarkan surat edaran dari Gubernur yang diterbitkan oleh BPKAD, itu adalah syarat atau acuan mutlak kita dalam menyusun anggaran”.

Tujuan dari penyusunan anggaran kas ini dimaksudkan agar setiap pelaksana kegiatan memiliki pedoman yang dapat dijadikan acuan agar setiap kegiatan tersebut menjadi terjadwal baik dari segi pelaksanaan dan pertanggungjawaban keuangannya, dengan kata lain membantu pelaksana kegiatan agar lebih tertib dalam melaksanakan kegiatan sesuai dengan jadwalnya. Jangan sampai kegiatan yang belum ada dianggaran kas tetapi justru dilaksanakan. Hal ini juga disampaikan Bendahara Pengeluaran kepada peneliti.

“...Memang anggaran kas juga sudahada kebijakan, triwulan satu, dua atau tiga dan empat. Jadi memang itu tetap, supaya untuk kita menjagajangan sampai terjadi istilahnya untuk memperkecil kesalahan seandainya satu kegiatan ini belum dianggarkan jangan sampai itu direalisasikan di triwulan pertama misalnya seperti itu,dan memang disini juga kita mengacu pada aplikasi di SIMDA, dalam hal ini kita di Biro Umum, jadi memang sudah ada ditetapkan sendiri anggaran triwulan satu, dua, tiga atau empat. Dan sebagai untuk kendali kita disini juga, teman-teman disini juga memangada istilahnya semacam buku kendali untuk anggaran kasnya. Ada acuannya memang, biasanya triwulan pertama itu sebesar $20 \%, 30 \%$, 30\% dan $20 \%$ jadi $100 \%$.

Penyusunan anggaran kas yang sudah ditentukan besaran persentasenya ini ternyata juga menimbulkan masalah bagi sebagian pelaksana kegiatan, beberapa berpendapat bahwa besaran persentase anggaran kas tersebut justru menghambat dalam merealisasikan anggaran karena diang- gap tidak fleksibel jika melihat dari kompleksitas pekerjaan yang ada pada pelaksana kegiatan. Ada yang beranggapan diawal terlalu kecil sedangkan diakhir terlalu besar, ada pula yang beranggapan yang harus besar itu di triwulan dua dan tiga sedangkan ditriwulan akhir itu cukup kecil saja. Pernyataan ini didapatkan dari keterangan yang diberikan oleh salah seorang PPTK kepada peneliti.

“...DiTAPD itu menetapkan anggaran kas, anggaran kas itu 20\% ditriwulan satu, 30\% ditriwulan dua. Sebenarnya memang pernah kita usulkan pola anggaran kas ini, harusnya ditriwulan satu itutidak perlu terlalu besar, ditriwulan dua ini yang harus besar. Kalau ini $20 \%, 30 \%, 30 \%, 20 \%$. Kalau saya seharusnya $10 \%, 60 \%$, diterkahirnya baru kecil, karena kalau diterakhirnya masih dikasi $20 \%$ bisa aja menumpuk, tapi kembali lagi ke pendapatan, seharusnya memang membuat anggaran kas itu tidak begitu, harusnya kalau kita memang punya kemampuan sudah di perencanaan itu jangan lagi $20 \%$ ditriwulan empat, itu $10 \%$ aja ditriwulan empat”.

Hal senada juga disampaikan oleh informan lain yang juga seorang PPTK yang kompleksitas pekerjaannya lebih banyak tidak dapat diprediksi karena semua tergantung dari kebijakan pimpinan.

“...Seperti yang saya bilang tadi seharusnya $20 \%$ waktu triwulan satu, contoh20\%, triwulan kedua $30 \%$, triwulan tiga $30 \%$, triwulan keempat 20\%.Itu sekali lagi kalau menurut saya pribadi harus fleksibel, fleksibel dalam arti dilihat dalam kompleksitas pekerjaannya, contoh saya dirumah tangga dengan dinamika kegiatan yang demikian banyak tidak bisa saya berpatokan pada itu (anggaran kas), kadangkadang itu kesulitan saya, tapi tetap sajasetiap penyusunan anggaran kas tentunya kita harus positif tingking, ini dimaksudkan agar kinerja itu selalu terukur, targetnya tercapai otomatis rapor SKPDnya baik”.

Di sisi lain penetapan besaran persentase anggaran kas ini juga sangat berdampak pada realisasi pelaksanaan kegiatan, karena terkadang pada Biro Umum Setda Provinsi NTB terdapat kegiatan yang membutuhkan anggaran yang cukup besar misalnya untuk pengadaan-pengadaan yang harus dilelang. Pengadaan-pengadaan yang dilelang ini tentu satuannya adalah paket sehingga anggarannya tidak mungkin dipecah-pecah. Tetapi yang terjadi terkadang pelakasana kegiatan harus memecah anggaran kegiatan tersebut karena 
mengacu pada pedoman persentase penyusunan anggaran kas. Jika anggaran kegiatan tersebut tidak didipecah akan berdampak juga pada anggaran kegiatan yang bersifat rutin. Maka dari itu pelaksana kegiatan tidak punya pilihan lain jika ingin melaksanakan kegiatan tersebut harus menunggu anggaran kas pada triwulan berikutnya agar anggarannya menjadi satu paket. Hal ini juga yang dirasakan oleh salah satu PPTK pada Biro Umum Setda Provinsi NTB yang diungkapkan pada saat wawancara.

“...Ini yang sulit, saya bilang belum sesuai, karena kita menetapkan, umpamanya anggaran ditriwulan dua atau ditriwulan tiga harusnya $80 \%$ contohnya, tapi kenyataannya ada anggaran yang tidak ada, kita tunggu digabungkan”.

Pernyataan tersebut juga senada dengan yang dikatakan oleh PPTK yang lain terkait permasalahan tersebut.

“...Karena ini menyangkut perencanaan sebenarnya, tidak berjalan juga, ini berpengaruh. Umpamanya kita laksanakan sudah kita dikasi 20\%, kita sebenarnya bisa melaksanakan ditriwulan satu itu kegiatan, tapi dananya dipecah, tidak mencukupi, akhirnya kita menunggu lagi, harus ngumpulin. Ini berpengaruh pada serapan, jadi gak berani dilaksanakan, tunggu klop dana dulu”.

Terlepas dari permasalahan mengenai besaran persentase anggaran kas, anggaran kas tersebut harus dususun oleh setiap SKPD. Pada Biro Umum Setda Provinsi NTB proses penyusunan anggaran kas dilakukan pertama kali oleh pelaksana kegiatan kemudian diusulkan ke Subbag Perencanaan untuk dimasukkan kedalam aplikasi SIMDA sehingga dokumen perencanaan dapat dicetak atau diterbitkan. Dalam penyusunan anggaran kas tentunya Subbag Perencanaan berkordinasi dengan masing-masing PPTK atau pembantu PPTK karena pada entitas inilah tempat kegiatan tersebut dilaksanakan. Hal ini disampaikan oleh PPK-SKPD yang juga sebagai Kepala Bagian Keuangan yang membawahi Subbag Perencanaan.

“...Sebagai perencana tidak serta merta kita mengetahui semua kegiatan yang akan kita laksanakan, karena perencanaan awal ini bermula tentunya dari masing-masing Subbag atau Pembantu PPTK. Jadi yang mengusulkan suatu kegiatan adalah pembantu PPTK yang harus mengetahui PPTK dan itu kemudian yang diusulkan kepada Kasubbag Perencanaan untuk dijadikan dasar penyusunan anggaran kas”.

Penjelasan diatas menggambarkan bagiamana kordinasi antara pelaksana kegiatan dan Subbag Perencanaan dalam penyusunan anggaran kas. Penyusunan anggaran kas tersebut diharapkan mampu menjadi pengendali arus kas pada Biro Umum Setda Provinsi NTB sehingga proses pelaksanaan kegiatan dan serapan anggaran menjadi lebih tertib. Akan tetapi berbeda dengan apa yang terjadi pada saat pelaksanaan, anggaran kas yang seharusnya digunakan sebagai pengendali arus kas tidak digunakan secara konsisten. Ini tidak menggambarkan kondisi yang ideal seperti apa yang diharapkan oleh sebuah organisasi. Tingkat serapan anggaran yang tidak sesuai dengan target persentase anggaran kas ini disinyalir disebabkan oleh berbagai faktor, seperti yang diungkapkan oleh PPK-SKPD ketika disinggung masalah konsistensi penyerapan anggaran terhadap anggaran kas.

“...Terkait penyerapan anggaran, setiap SKPD punya permasalahan atau punya situasi masing-masing. Disini Biro Umum karena unit kerja yang melayani pimpinan, Biro Umum punya keunikan sendiri terhadap pelaksanaan anggaran. Karena misalkan sebuah kegiatan yang kita usulkan atau kita anggarkan ditriwulan pertama, ini saya ambilkan contoh pada fisik karena berdasarkan arahan atau adaran dari pimpinan bahwa untuk pekerjaan fisik harus kita anggarkan pada triwulan pertama, tetapi dalam pelaksanaannya dilapangan terkadang kita membutuhkan atau ada suatu kebijakan tertentu yang dikeluarkan oleh pimpinan, salah satu contohnya tadi yang bersifat fisik. Sehingga dengan adanya kebijakan itu otomatis pekerjaanpekerjaan fisik yang kita anggarkan itu menjadi tertunda dan otomatis anggaran kas yang kita rencanakan itu tidak bisa kita laksanakan karena edaran tadi atau kebijakan”.

Hal senada juga diungkapkan oleh PPK Biro Umum Setda Provinsi NTB terkait permasalahanpermasalahan yang dihadapi pada saat pelaksanaan sehingga terjadinya inkonsistensi penyerapan anggaran terhadap anggaran kas. Berikut petikan wawancaranya.

“...Memang seperti kita ketahui, Biro Umum itu basicnya adalah pelayanan, pelayanan ke pimpinan. Pelayanan itu memang kadang- 
kadang tidakserta merta harus kita jadwalkan kita contohkan belanja makan minum tamu, itu tergantung tamunya, gak mungkin kita harus paskan tamunya semester ini harus 1000 misalnya, tamunya besok 1000 juga, bagi rata, tapi ketika tiba-tiba mungkin lagi tidak ada event-event, kosong misalnya tamu, serapan kita rendah, karena itu basicnya pelayanan memang kita sudah diberikan anggaran kas, tetapi sifat kita yang pelayanan itu bisa dikatakan unik".

Contoh permasalahan yang diungkapkan oleh kedua informan tersebut adalah salah satu contoh yang dihadapi pada saat pelaksanaan kegiatan selain masih banyak contoh-contoh lain. Pada saat pelaksanaan kegiatan sebenarnya Biro Umum Setda Provinsi NTB berusaha untuk konsisten dalam merealisasikan kegiatan baik secara keuangan maupun secara fisik sesuai dengan target yang ada pada anggaran kas, tetapi kembali lagi kepada tugas dan fungsi dari Biro Umum Setda Provinsi NTB yang sebagian besar melayani pimpinan sehingga sebagian besar kegiatannya dipengaruhi oleh kebijakan pimpinan baik pimpinan daerah maupun pimpinan SKPD tersebut. Beberapa informan berdasarkan hasil wawancara membenarkan hal tersebut, antara lain PPK ketika disinggung tentang hal tersebut.

“...Kita sebenarnya mau konsisten, tapi karena ada hal-hal diluar itu yang menjadi salah satu kenapa mungkin target kita tidak pas-pas sekali. Kemudian juga misalnya kita ada rencana belanjafisik, tapi ketika dalam tahap perencanaan itu misalnya ada kendalakendala, bisa jadianggaran kas yang sudah kita rencanakan tidak konsisten, tidak terlaksana sesuai dengan harapan, jadinya anggaran kas kita tertunda”.

Lebih lanjut informan lain seperti Bendahara Pengeluaran juga memberikan keterangan yang sama.

“...Kita berusaha konsisten sebenarnya. Jadi karena di Biro Umum ini terkait pelayanan pimpinan, jadi agak lebih komplit permasalahannya di Biro Umum ini. Kalau untuk seperti tadi konsisten memang kita terus berusaha untuk bisa sesuai dengan yang sudah direncanakan ataupun dengan anggaran yang sudah dipersiapkan”.

Penyerapan anggaran yang tidak berjalan konsisten ini dapat terlihat dari tidak tertibnya pelaksana kegiatan dalam merealisasikan kegiatan- nya, ini terbukti adanya kegiatan yang dilaksanakan tidak sesuai dengan perencanaan anggaran kas yang telah disusun sebelumnya. Kejadian ini mengindikasikan bahwa tidak tuntasnya proses perencanaan, karena ketika pada proses pelaksanaan ada kegiatan yang dilaksanakan tetapi anggaran kasnya tidak tersedia, begitu juga sebaliknya ada ketika anggaran kasnya sudah tersedia tetapi kegiatan tersebut justru tidak dilaksanakan. Kutipan wawancara dengan PPK berikut mengindikasikan bahwa kejadian tersebut terkadang terjadi.

“...Memang ada, kita tidak memungkiri itu, karena sifatnya pelayanan, seperti yang saya sampaikan tadi memang kita sudah merencanakan sesuatu tapi karena kita sifatnya layanan jadi anggaran kas kadang tidak sesuai dengan waktu, kemudian juga pemeliharaan-pemeliharaan itu juga sangat dipengaruhi memang oleh kondisi real”.

Menurut salah seorang PPTK, kejadian seperti ini terjadi diakibatkan karena melihat dari dinamika kegiatan yang ada. Kegiatan-kegiatan yang dilaksanakan sebagian besar mengikuti kebijakan pimpinan daerah sehingga sering kali pelaksanaan kegiatan tidak sesuai dengan jadwal yang ada yang berpengaruh terhadap serapan anggaran pada setiap triwulannya. Berikut petikan wawancaranya.

“...Kalau saya sering mengalami yang anggaran kasnya sudah tidak ada tetapi pagu dananya secara umum masih ada tapi karena direktif pimpinan harus saya laksanakan. Terkait dengan hal ini sekali lagi tentunya iniadalah mekanisme yang wajar dilihat dari dinamikanya sekali lagi, bagi saya yang penting pagu dananya ada”.

Dinamika kegiatan yang dilaksanakan oleh Biro Umum Setda Provinsi NTB memang menjadi permasalahan tersendiri yang kompleks terhadap penyerapan anggarannya, sehingga terkadang terlihat kecil pada salah satu triwulan tetapi terkadang juga tiba-tiba langsung melonjak besar pada triwulan yang lain. Terkait dengan permasalahan tersebut, sebenarnya anggaran kas itu dapat dievaluasi dengan melakukan revisi anggaran kas. Revisi anggaran kas dilakukan sesuai dengan kebutuhan dan aturan yang berlaku sesuai dengan besaran persentase yang telah ditetapkan. Karena harus tetap berdasarkan persentase yang ada, revisi anggaran kas tersebut dilakukan dengan 
cara menggeser anggaran kas yang kegiatannya belum dilaksanakan diganti dengan anggaran kas yang kegiatannya harus segera dilaksanakan. Dalam wawancara yang dilakukan, PPK-SKPD membenarkan hal tersebut jika dijumpai permasalahan seperti itu pada saat pelaksanaan.

\begin{abstract}
“...Kita diberikan target untuk penyerapan anggaran misalkan di triwulan pertama $20 \%$, triwulan dua $30 \%$, triwulan tiga $30 \%$ dan triwulan empat 20\%. Jadimisalkan ada kegiatan-kegiatan yang sudah kita pastikan tidak bisa kita laksanakan atau ada kegiatan lain di triwulan berikutnya yang harus segera kita laksanakan di triwulan awal, itu kita bisa mengadakan revisi, jadiberdasarkan kebijakankebijakan pimpinan atau berdasarkan kondisi di lapangan kita bisa menyesuaikan melalui revisi anggaran kas”.
\end{abstract}

Senada dengan apa yang dikatakan PPKSKPD tersebut, PPK juga memberikan keterangan bahwa revisi anggaran kas dapat dilakukan. Terlebih lagi PPK menyebutkan bahwa pada Biro Umum Setda Provinsi NTB ini telah beberapa kali melakukan revisi anggaran kas karena memang berdasarkan kebutuhan. Berikut petikan wawancaranya.

“...Kalau tidak salah memang anggaran kas itu beberapa kali kita revisi, setelah kita evaluasi ternyata ada hal-halnya yang lebih mendesak untuk direalisasikan pada triwulan pertama misalnyayang sebenarnya kita anggarkan di triwulan berikutnya itu bisa dikoreksi. Cuman kita untuk mengkoreksi anggaran kas itu harus ada alasan, memang kajian yang jelas dan real kenapa anggaran kas itu kira-kira kita revisi”.

Revisi anggaran kas ini membutuhkan waktu untuk prosesnya, karena anggaran kas ini termasuk dalam dokumen perencanaan. Usulan revisi anggaran kas ini disampaikan oleh pelaksana kegiatan kepada kepala SKPD melalui Subbag Perencanaan dengan melampirkan alasan serta kajian sebagai dasar perubahan anggaran kas. Usulan revisi anggaran kas tersebut disampaikan ke PPKD (Pejabat Pengelola Keuangan Daerah) untuk diproses didalam aplikasi SIMDA Keuangan dan disahkan oleh Kepala BPKAD selaku PPKD. Proses birokrasi seperti itulah yang terkadang memerlukan waktu yang sedikit lama karena harus melewati beberapa tahapan dan persetujuan berbagai pihak. Karena proses administrasinya yang memerlukan waktu tentunya proses pertanggungjawabannya menjadi terhambat walaupun sebenarnya kegiatan tersebut sudah dilaksanakan. Ini berpengaruh terhadap serapan anggaran karena jika suatu kegiatan belum merealisasikan anggarannya sering dianggap kegiatan tersebut belum dilaksanakan. Tolok ukur keberhasilan suatu SKPD untuk saat ini masih sering dilihat dari serapan anggaran yang tinggi dan konsisten.

\section{SIMPULAN}

Pendekatan kualitatif digunakan dalam penelitian ini untuk mengetahui faktor-faktor penyebab terlambatnya serapan anggaran yang mempengaruhi tingkat serapan anggaran khususnya pada awal tahun anggaran yang dilihat dari sudut pandang individu/aktor yang berhubungan langsung dengan proses realisasi anggaran. Individu/aktor tersebut adalah pejabat-pejabat pengelola keuangan pada Biro Umum Setda Provinsi NTB yang memiliki pengalaman pada proses tersebut. Berdasarkan hasil wawancara mendalam sebagai dasar proses analisis dan penyajian data, maka ditemukan simpulan yang menjadi penyebab rendahnya tingkat serapan anggaran Biro Umum Setda Provinsi NTB pada awal tahun anggaran yang dapat dikelompokkan menjadi tiga faktor yaitu : (1) Faktor Sumber Daya Manusia, (2) Faktor Administrasi, dan (3) Faktor Kebijakan.

Sumber daya manusia dalam dalam sebuah organisasi sangatlah penting, begitu juga dengan SDM yang ditunjuk sebagai pejabat pengelola keuangan pada Biro Umum Setda Provinsi NTB. Akan tetapi terkadang tidak semua pejabat pengelola keuangan yang ditunjuk paham terhadap pengelolaan keuangan, karena ada pejabat pengelola keuangan itu melekat terhadap tugas dan fungsinya sebagai pejabat struktural contohnya PA, KPA dan PPTK. Ini terkadang yang menyebabkan proses penatausahaan keuangan pada Biro Umum Setda Provinsi NTB ini menjadi terhambat karena kurang pahamnya pejabat tersebut terhadap pengelolaan keuangan.

Faktor administrasi juga berpengaruh terhadap serapan anggaran jika proses administrasinya terlambat. Contohnya terlambat diterbitkannya SK sebagai payung hukum untuk pelaksanaan kegiatan. Karena menganut sistem legalitas, SK tersebut menjadi sangat penting karena semua pelaksanaan kegiatan dan penunjukan pejabatpejabat pengelola keuangan harus dilegalkan dalam bentuk surat keputusan yang disahkan oleh 
pejabat yang berwenang. Begitu juga dengan revisi DPA yang dapat menghambat proses realisasi, karena proses pertanggungjawaban kegiatan tidak dapat dilaksanakan jika kegiatan tersebut dokumen perencanaannya masih dalam tahap revisi. Kedua hal tersebut biasa dilakukan pada saat awal tahun anggaran sehingga kegiatan-kegiatan yang berhubungan dengan kedua hal tersebut menjadi terhambat pelaksanaannya.

Dalam pelaksanaan kegiatan kebijakankebijakan pimpinan juga menjadi pertimbangan yang harus dilihat efeknya terhadap tingkat serapan anggaran. Terkadang kebijakan tersebut justru dapat menghambat realisasi anggaran seperti halnya di Biro Umum Setda Provinsi NTB yang tugas dan fungsinya sebagai palayanan terhadap pimpinan. Jika berhubungan dengan pimpinan tentu sebagian besar kegiatannya berdasarkan kebijakan dari pimpinan dalam hal ini $\mathrm{KDH} /$ WKDH. Hal inilah yang terkadang menjadi faktor yang membuat serapan anggaran tidak berjalan konsisten sesuai dengan target yang telah disusun dalam anggaran kas. Anggaran kas digunakan untuk mengendalikan arus kas keluar agar menjadi lebih tertib dan terkendali.

Secara garis besar, dibalik permasalahanpermasalahan yang dialami yang mempengaruhi tingkat serapan anggaran Biro Umum Setda Provinsi NTB pada awal tahun anggaran, realisasi anggaran pada akhir tahun anggaran Biro Umum Setda Provinsi NTB terbilang cukup baik karena walaupun terjadi permasalahan, Biro Umum Setda Provinsi NTB mampu untuk mencari solusi dari permasalahan yang ditimbulkan dan dapat merealisasikan anggarannya tepat dalam waktu satu tahun anggaran.

Dari hasil penelitian yang dilakukan pada Biro Umum Setda Provinsi NTB mengenai faktor-faktor yang mempengaruhi serapan anggaran pada Biro Umum Setda Provinsi NTB, maka ada beberapa rekomendasi saran yang dapat peneliti sampaikan adalah sebagai berikut: (1) Seluruh pimpinan pada Biro Umum Setda Provinsi NTB seharusnya memiliki komitmen untuk mengawal pelaksanaan anggaran, pelaksanaan kegiatan khususnya pada proses perencanaan yang harus tuntas agar tidak sering terjadi revisi terhadap dokumen perencanaan tersebut, (2) Diharapkan PPTK dan pembantu PPTK dalam mengusulkan kegiatnnya tersebut harus berdasarkan kebutuhan bukan berdasarkan keinginan, atau memiliki skala prioritas, (3) Dalam setiap kegiatan seharusnya dilengkapi dengan kerangka acuan atau TOR sehingga jelas dalam melakukan kegiatan itu apa dasar hukumnya, kapan kegiatannya, berapa jumlah biayanya itu harus jelas, ini dilakukan untuk meminimalisir kesalahan pada saat pelaksanaannya, (4) Di dalam melaksanakan program dan kegiatan seharusnya ada sumber daya manusia yang berkompeten agar nantinya setiap pelaksanaan pekerjaan pada Biro Umum Setda Provinsi NTB dapat dipertanggung jawabkan dan bukan hanya sekedar menyelelesaikan pekerjaan yang telah diprogramkan saja, (5) Perlu diadakan bimbingan teknis untuk para pejabat pengelola keuangan yang jabatannya melekat pada tugas dan fungsi jabatan struktural sehingga paham terhadap pengelolaan keuangan.

Penelitian ini memiliki keterbatasan, diantaranya adalah deskripsi faktor-faktor yang menyebabkan terjadinya keterlambatan penyerapan anggaran hanya diungkap dari satu sisi yakni argumentasi yang disampaikan oleh pihak internal SKPD. Lebih jauh, penelitian ini belum mampu mengungkap atau mengeksplorasi argumentasi terjadinya keterlambatan penyerapan anggaran dari pihak eksternal SKPD. Keterbatasan dalam penelitian ini dapat menjadi "bahan" untuk menjadi pengembangan dalam penelitian selanjutnya. Penelitian ini dapat dikembangkan dengan penelitan kualitatif yang lebih kompleks dan mendalam, seperti dengan pendekatan studi kasus dengan melihat keterkaitan kasus yang terjadi di tingkat internal dan eksternal SKPD. Penggunaan model riset campuran juga dianjurkan agar dapat menghasilkan temuan penelitian yang lebh kaya (Sofyani dan Akbar, 2013; 2015).

\section{DAFTAR PUSTAKA}

Arif, E. 2011. Identifikasi Faktor-faktor Penyebab Minimnya Penyerapan Anggaran Pendapatan Belanja Daerah (APBD) Kabupaten/Kota di Provinsi Riau Tahun 2011. Jurnal Ekonomi, Manajemen dan Akutansi,, 19 (2), 45-199.

Kuncoro, D. E. 2013. Analisis Penyerapan Anggaran Pasca Penerapan Aplikasi Sipp Pada Satker Pelaksanaan Jalan Nasional Wil. I Dinas Pu Prov. Kaltim. E-Journal Administrasi Bisnis, 1 (4), 364-373.

Latuconsina, Y. M. 2016. Mengungkap Fenomena Potongan Angsuran Murabahah di Perbankan Syariah. Jurnal Akuntansi dan Investasi, 17 (2), 132-140. 
Mahsun, F.S. dan A. P. Heribertus. 2011. Akuntansi Sektor Publik. Yogyakarta: BPFE.

Mangkoesoebroto, G. 2001. Ekonomi Publik. Yogyakarta: BPFE UGM.

Peraturan Menteri Dalam Negeri Nomor 13 Tahun 2006tentang Pengelolaan Keuangan Daerah.

Peraturan Daerah Provinsi Nusa Tenggara Barat Nomor 11 Tahun 2014 tentang Perubahan Kedua atas Peraturan Daerah Provinsi Nusa Tenggara Barat Nomor 6 Tahun 2008 tentang Organisasi dan Tata Kerja Sekretariat Daerah Provinsi Nusa Tenggara Barat dan Sekretariat Dewan Perwakilan Rakyat Daerah Provinsi Nusa Tenggara Barat.

Putri, C. T. dan Fachruzzaman. 2014. Analisis Faktor-Faktor yang Mempengaruhi Penyerapan Anggaran pada Satuan Kerja Perangkat Daerah di Pemerintah Provinsi Bengkulu. Skripsi, Universitas Bengkulu.

Rahayu, S. 2007. Studi Fenomenologis terhadap Proses Penyusunan Anggaran Daerah (Bukti Empiris dari satu Satuan Kerja Perangkat Daerah di Provinsi Jambi). Paper Dipresentasikan Pada Simposium Nasional Akuntansi X, Makassar.

Rozai, M. A. dan L., Subagiyo. 2015. Optimalisasi penyerapan anggaran dalam rangka pencapaian kinerja organisasi (Studi Kasus : Inspektorat Kabupaten Boyolali). Jurnal Manajemen Sumberdaya Manusia, 9 (1), 72-89.

Samuelson, P. A. dan W. D., Nordhaus. 1996. Makro Ekonomi. Edisi ke-. 17. Cetakan ketiga. Jakarta: Erlangga.

Saridewi, A. A. A. N., P. A., Noak., dan N. W. Supriliyani. 2013. Analisis faktor-faktor yang mempengaruhi realisasi anggaran pendapatan dan belanja daerah(Studi Kasus : Anggaran Dinas Pekerjaan Umum Kota Denpasar Tahun 2013). E-Journal Universitas Udayana, 1 (2), 12827-23800.

Sarosa, S. 2012. Penelitian Kualitatif. Jakarta Barat: Indeks.

Sofyani, H. dan R. Akbar. 2013. Hubungan Faktor Internal Institusi dan Implementasi Sistem Akuntabilitas Kinerja Instansi Pemerintah (SAKIP) di Pemerintah Daerah. Jurnal Akuntansi dan Keuangan Indonesia, 10(2), 184-205.

Sofyani, H. dan R. Akbar. 2015. Hubungan karakteristik pegawai pemerintah daerah dan implementasi sistem pengukuran kinerja: Perspektif ismorfisma institusional. Jurnal Akuntansi dan Auditing Indonesia, 19 (2), 153-173.

Sugiyono. 2015. Memahami penelitian kualitatif. Bandung: Alfabeta.

Sugiyono. 2014. Metode Penelitian Kuantitatif, Kualitatif dan R\&D, Cetakan kedelapanbelas. Bandung; Penerbit CV Alfabeta.

Undang-Undang Nomor 22 Tahun 1999tentang Pemerintah Daerah.

Undang-Undang Nomor 17 Tahun 2003 tentang Keuangan Negara.

Undang-Undang Nomor 32 Tahun 2004 tentang Pemerintah Daerah.

Yuwono, S. 2008. Memahami APBD dan Permasalahannya: Panduan Pengelolaan Keuangan Daerah. Malang: Bayumedia. 